\title{
Piglet Feed Contaminated with Aflatoxin B1 and Supplemented with an Anti-Mycotoxin Blend: Impact on Health and Zootechnical Performance
}

\section{Lara Tarasconi}

UDESC: Universidade do Estado de Santa Catarina

Vanessa Dazuk

UDESC: Universidade do Estado de Santa Catarina

Vitor Molosse

UDESC: Universidade do Estado de Santa Catarina

\section{Bruno Cecere}

UDESC: Universidade do Estado de Santa Catarina

Guilherme Deolindo

UDESC: Universidade do Estado de Santa Catarina

João Strapazzon

UDESC: Universidade do Estado de Santa Catarina

Nathieli Bottari

UFSM: Universidade Federal de Santa Maria

Priscilla Copetti

UFSM: Universidade Federal de Santa Maria

Vera Morsch

UFSM: Universidade Federal de Santa Maria

\section{Laercio Sareta}

IFC

\section{Ricardo Mendes}

IFC

\section{Marcelo Vedovatto}

Universidade Estadual do Mato Grosso do Sul

Eduardo Micotti

USP

Eduardo Ternus

Vetanco

Diovani Paiano

UDESC: Universidade do Estado de Santa Catarina

Aleksandro Da Silva ( $\nabla$ aleksandro.silva@udesc.br)

Universidade do Estado de Santa Catarina https://orcid.org/0000-0002-9860-1933

\section{Research Article}

Keywords: Pigs, Mycotoxin, Adsorbents, Performance 
Posted Date: August 25th, 2021

DOI: https://doi.org/10.21203/rs.3.rs-630039/v1

License: (c) (i) This work is licensed under a Creative Commons Attribution 4.0 International License. Read Full License 


\section{Abstract}

The present study aimed to determine whether the inclusion of a mixture based on Saccharomyces cerevisiae lysate, zeolite, silicon dioxide, propylene glycol, Carduus marianus extract, soy lecithin, and carbonate in the piglet diet would be able to minimize the negative effects caused by feed with aflatoxin; a study focusing on animal health and performance. Seventy-two entire male piglets $(7.35 \pm 1.17 \mathrm{~kg})$ weaned with an average of 26 days were used, allotted into four groups, with six repetitions (pens) per group and three piglets/pen. The treatments were as follows: NoAflaNoAntiMyc - negative control (without aflatoxin); Afla-NoAntiMyc - positive control (500 ppb of aflatoxin); NoAflaAntiMyc - $1000 \mathrm{mg} / \mathrm{kg}$ of anti-mycotoxin mixture; Afla-AntiMyc $-500 \mathrm{ppb}$ aflatoxin $+1000 \mathrm{mg} / \mathrm{kg}$ anti-mycotoxin. We evaluated the performance (feed intake - Fl, weight gain - WG and feed:gain ratio- FGR) andblood variables (10 days between samples). On day 32, six pigs from each group (a total of 24 pigs) were slaughtered to collect fragments of the liver, intestine, and spleen for analysis of oxidants/antioxidants and histology. It was observed that piglets in the positive control group (Afla-NoAntiMyc) had lower body weight and weight gain when compared to the other groups during the experimental period. Also, piglets from Afla-NoAntiMyc consumed less feed between days 1 to 20 and 1 to 30 compared to NoAfla-NoAntiMyc. A considerable increase in liver enzymes aspartate aminotransferase and alanine aminotransferase in the piglets' serum of Afla-NoAntiMyc compared to other treatments, which indicates that the antiaflatoxin blend worked. Fewer neutrophils and an increase in monocyte were observed in the piglets of Afla-NoAntiMyc compared to NoAfla-NoAntiMyc; changes that were not seen in the animals of Afla-AntiMyc. We did not see any change in the oxidant and antioxidant status in the piglet serum during the experimental period; different from what happened in Afla-NoAntiMyc piglets in the liver (higher glutathione reductase activity and levels of reactive oxygen species - ROS), in the spleen (higher levels of ROS) and the intestine/jejunum (reduction of nitrate/nitrite levels - NOx). Intestinal morphometry revealed that piglets from Afla-NoAntiMyc had higher villus height than the other groups, while the folded size was smaller in this group. The crypt depth was greater in the intestine of piglets in both treatments that consumed aflatoxin. In general, it is concluded that the consumption of aflatoxin B1 by piglets has negative impacts on the health and, consequently, the animals' performance; however, supplementation of the contaminated feed with an antimycotoxin blend was able to protect the piglets, minimizing the negative problems caused by the mycotoxin.

\section{Introduction}

One of the biggest recurring challenges in production, animal development, and, consequently, in pig farming is directly linked to the food and the feed's quality. The grains present in the feed, when not produced and stored in adequate conditions, of temperature and humidity, can undergo physical and chemical changes, losing their nutritional values, facilitating the appearance of toxic substances, and consequently hindering the performance of these contaminated animals (Dias, 2020). in 2013 found that 81\% (3000 samples) were contaminated by at least one mycotoxin (Murugesan, 2015). It is important to remember that these mycotoxins are toxic substances from the metabolism of several fungi, which, when present in the feed, end up interfering in the health of animals and causing the death of piglets in maternity centers (Bretas, 2018).

Among the various mycotoxins present in cereals, we highlight here aflatoxin, responsible for significant losses in pig farming (Souto, 2017). Fungi of the genus Aspergillus sp. produce aflatoxin, a microorganism ubiquitous in sorghum and corn crops (Bünzen, 2006). Today it is known that the main organ affected by this mycotoxin is the liver, which can be responsible for the appearance of liver carcinomas when ingested by the animal in low doses over a prolonged period and cause acute hepatotoxic effects when in high doses in a short interval of time (Rocha, 2008). In addition to liver problems and low growth, the animal's immune system can be negatively affected, thus facilitating bacterial and viral infections (Bünzen, 2006). It is essential to know that the susceptibility to aflatoxins varies according to the species considered and the age of the animals, with young people being more sensitive (Kelllerman, 1990). In piglets in the 
nursery and growing phase, morbidity reached $97 \%$, among 68 of the 70 animals; however, the younger animals were more susceptible to aflatoxicosis outbreaks (Schoenau, 1994).

Foods contaminated with aflatoxin directly reach productivity, which has forced the search for strategies to prevent or reduce this intoxication in animals (Ramos, 1996). One of the productive sector alternatives is prophylactically protecting animals by adding adsorbents to the feed (Huwig, 2001). These adsorbents are also known as mycotoxin

binders and sequestering as agents that act directly on the intestinal tract, decreasing the absorption of these toxins and promoting their excretion through urine or feces (Haque, 2020). Considering that the use of adsorbents is an effective way and one of the main methods used to prevent possible pathologies arising from the ingestion of mycotoxins in piglets (Bretas, 2018), the present work brought as a strategy the use of a blend that among its ingredients has the $C$. marianum, an extract rich in silymarin, with the hypothesis that it would minimize adverse effects caused by aflatoxin, due to acting as a hepatoprotective (Magliulo, 1979; Lorenz, 1984; Valenzuela, 1985; Yao-Cheng, 1991; Conti, 1992; Muriel, 1992; Haková, 1993; Wu, 1993). Another ingredient in the blend was Saccharomyces cerevisiae lysate, which has high levels of complex B vitamin and can stimulate the immune system, which has already resulted in better feed:gain ratio and weight gain (Simon, 2001); and soy lecithin with its antioxidant action (Marconcin, 2009); among the other strategic ingredients.

We hypothesize that the blend can neutralize the adverse effects of experimental aflatoxicosis, directly or indirectly, avoiding production losses in cases of contamination of piglets' food by aflatoxin. Thus, the objective of this research was to determine whether the inclusion of a mix based on $S$. cerevisiae lysate, zeolite, silicon dioxide, propylene glycol, C. marianus extract, soy lecithin, and carbonate in the piglet diet would be able to minimize the adverse effects caused by the daily intake of aflatoxin; this study focused on pig performance and health.

\section{Materials And Methods}

\subsection{Anti-mycotoxin commercial product}

We used commercial products based on S. cerevisiae lysate, zeolite, silicon dioxide, propylene glycol, C. marianus extract, soy lecithin, and calcium carbonate.

\subsection{Aflatoxin production and analysis}

Aflatoxins were produced by the ATCC 13608 strain of Aspergillus flavus during fermentation of converted rice, and the following protocol was used. Erlenmeyer flasks of $500 \mathrm{~mL}$ volume were used to receive $100 \mathrm{~g}$ of rice. At least $2 \mathrm{~h}$ before the sterilization of 40 distilled water was added to a flask and mixed with rice. The sterilization was performed at $121^{\circ} \mathrm{C}$ for 30 minutes, and then the flasks were left to lose temperature before inoculation. The rice was inoculated with $2 \mathrm{~mL}$ of 108 spore $\mathrm{mL}^{-1}$ of spore suspension of $A$. flavus. The incubation was carried out for 21 days at a controlled temperature $\left(25^{\circ} \mathrm{C}\right)$ and constant stirring of flasks. After incubation, the fermented material was dried in an oven at 50 ${ }^{\circ} \mathrm{C}$ and ground. The concentration of aflatoxin in the inoculum was determined in advance in order to calculate and determined the amount added in the diets in order to obtain a 500 ppb contamination, a dose already described in the literature for impairing pig performance (Schell et al., 1993).

Samples of feed and inoculum were ground to $<0.85 \mathrm{~mm}$ material, and $1 \mathrm{~g}$ of the ground material was transferred to a test tube of $50 \mathrm{~mL}$. It was added $10 \mathrm{~mL}$ of ultrapure water and $10 \mathrm{~mL}$ of acetonitrile/acetic acid $(\mathrm{CH} 3 \mathrm{CN}: \mathrm{CH} 3 \mathrm{COOH})$ [99.5:0.5, v/v], and the test tube was placed in a mechanic shaker for $10 \mathrm{~min}$. A mixture of $4 \mathrm{~g}$ of $\mathrm{MgSO} 4$ and $1 \mathrm{~g} \mathrm{of} \mathrm{NaCl}$ was, added and the tube was vigorously shaken for $10 \mathrm{~s}$. The solution was centrifuged for $15 \mathrm{~min}$ at $5.000 \times \mathrm{g}$, at, $25 \circ \mathrm{C}$ and $2.5 \mathrm{~mL}$ of supernatant was transferred to capped glass test tube where $2.5 \mathrm{~mL}$ of hexane was added. The solution was shaken for $2 \mathrm{~h}$ and then centrifuged at $1,000 \mathrm{xg}$ at $20^{\circ} \mathrm{C}$ for $1 \mathrm{~min}$. The lower phase (acetonitrile) $1 \mathrm{~mL}$ was 
withdrawn and dried with a nitrogen (N2) stream at $40^{\circ} \mathrm{C}$. The reconstitution was performed with $75 \mu \mathrm{L}$ of methanol in an ultrasonic bath for $10 \mathrm{~s}$ and $10 \mathrm{~s}$ in a test tube mixer after adding $75 \mu \mathrm{L}$ of ultrapure water. After centrifugation for 10 min at $14,000 \times g, 60 \mu \mathrm{L}$ was withdrawn and transferred to a vial where $140 \mu \mathrm{L}$ of ultrapure water was added. Ten microliters were injected into a chromatographic system.

Detection and quantification of aflatoxins were performed with high-performance liquid chromatography coupled with a mass spectrometer (LC/MS/MS). Chromatographic separation was carried out using Acqulty UPLC System (Waters, Milford, Massachusetts, US) equipped with $100 \times 2.1 \mathrm{~mm}, 1.7 \mu \mathrm{m}$ Acquity UPLC BEH C18 column (Waters, Milford, Massachusetts, US). The column was maintained at $40 \circ \mathrm{C}$, and the injection volume was $10 \mu \mathrm{L}$. The mobile phase consisted of $0.1 \%$ formic acid in water (A) and $0.1 \%$ formic acid in acetonitrile (B). The acetonitrile (B) concentration was raised gradually from $10-90 \%$ within 12 min, brought back to the initial conditions at $0.1 \mathrm{~min}$, and allowed to stabilize for $3 \mathrm{~min}$. The mobile phase was delivered at a flow rate of $0.4 \mathrm{~mL} / \mathrm{min}$. The LC system was coupled with Xevo TQS tandem mass spectrometer (Waters, Milford, Massachusetts, US), equipped with a turbo-ion electrospray (ESI) ion source. The mass spectrometer was operated in scheduled multiple reaction monitoring (MRM) in positive mode. The electrospray ionization and MS/MS conditions as shown in Supplementary Material 1.

\subsection{Animals and experimental design and Nutritional analysis}

The experiment was carried out in the experimental pig facilities at the Experimental Farm of the State University of Santa Catarina (FECEO), located in Guatambu, SC, Brazil, over 40 days. According to the nutritional requirements of pigs, the diet (mash) was based on corn, soybean meal, and commercial basemix to meet the nutritional requirements of pigs. Previous the corn grain was cleaning by rotary sieve machine ( $5 \mathrm{~mm}$ of aperture of sieves) to remove broken grains, sand and other small impurities.

We used 72 entire male piglets $(7.35 \pm 1.17 \mathrm{~kg})$ weaned with an average of 26 days, allotted into four groups with six replicates (six pens with 3 piglets). The experiment was conducted in a nursery facility fitted with a plastic floor, linear feeder (15cm/pigs) nipple drinker (minimum flow rate $1 / \mathrm{L} / \mathrm{min}$ ). The facilities' temperature was maintained with a convective automated heating system $\left(5,400 \mathrm{~W}\right.$ heaters), activate at $28^{\circ} \mathrm{C}$ and deactivate at $29^{\circ} \mathrm{C}$, additional heaters $(1,200 \mathrm{~W})$ were positioned in the corner's facilites (with the same set) as additional measure to meet the adequate temperature the temperature program was reduced $1^{\circ} \mathrm{C}$ per week (Supplementary Fig. 1). Dry bulb temperature was recorded using dataloggers (Probe type 18b20) positioned in the geometric center of the installation with $1 \mathrm{~h}$ sampling intervals (Supplementary Fig. 1).

The treatments were as follows: NoAfla, negative control (without aflatoxin); Afla, positive control (500 ppb of aflatoxin); Anti-Myc, 1000 mg/kg of the anti-mycotoxin blend; and Afla + Anti-Myc, 500 ppb of aflatoxin $+1000 \mathrm{mg} / \mathrm{kg}$ of Afla + AntiMyc.

After the analyzes described in Sect. 2.2, we verify that the actual contaminated diets to aflatoxin were as follows: NoAfla (AFLAB1 = 0.0 ppb; AFLAB2 = 0.0 ppb); Afla (AFLAB1 = 471.8 ppb; AFLAB2 = 8.2 ppb); Anti-Myc (AFLAB1 = 0.0 ppb; AFLAB2 = 0.0 ppb); Afla + Anti-Myc (AFLAB1 = 482.7 ppb; AFLAB2 = 11.1 ppb). AFLAG1 and AFLAG2 not observed in experimental feed.

The diets (mash form) from each phase and treatment were ground (mesh $1 \mathrm{~mm}$ ) and analyzed dry matter (DM, 930.15), ash (942.05) and crude protein (990.03) content following AOAC International (2005) methods (Supplementary Material 2).

\subsection{Zootechnical performance}


The zootechnical performance was evaluated at the end of the steps I (0-10 days), II (11-20 d), III (21-30 d) and IV (31-40 d) of the experimental periods. Pig weight were recorded an electronic scale (model DIGI-TRON UL-5 $\pm 50 \mathrm{~g}$ ) and feed intake recorded an electronic scale (Toledo $\pm 5 \mathrm{~g}$ ). Were calculated the daily feed intake, daily weight gain and feed:gain ratio calculated per pen

\subsection{Sample collection}

Blood samples were collected in vacutainer tubes on days $0,10,20,30$, and 40 of the experimental periods in tubes containing anticoagulants by trained staff. First, complete blood counts were performed according to the methodology described below. A $0.5 \mathrm{~mL}$ aliquot of blood was removed to analyze catalase (CAT) and superoxide dismutase (SOD) activity and stored frozen. Subsequently, blood was centrifuged at 8,000 rpm for 5 minutes, thereby obtaining serum allocated in a microtube and maintained frozen $\left(-20^{\circ} \mathrm{C}\right)$ until biochemical analysis.

On day 32 of the experiment, six pigs from each group were slaughtered in a specialized slaughterhouse, according to the inspection system's current legislation. Fragments of the liver, intestine, and spleen were collected, and samples were preserved in $10 \%$ formaldehyde. A liver fragment was homogenized in saline, centrifuged, and the supernatants were removed. These were packed in microtubes and frozen for further analysis of oxidants/antioxidants.

\subsection{Hemogram}

According to the manufacturer's recommendations, the hemoglobin, total leukocyte, and erythrocyte contents were determined using a commercial kit. In the sampling, blood smears were made and stained with commercial dye (Rapid Panotype) to perform differential leukocyte counts under a light microscope with a $1000 \mathrm{x}$ magnification, as described by Lucas and Jamroz (1961). Hematocrit was measured using microcapillary tubes, centrifuged at $14000 \times g$ for 5 min.

\subsection{Serum biochemistry}

Serum levels of total proteins, albumin, cholesterol, triglycerides, alanine aminotransferase (ALT), and aspartate aminotransferase (AST) were measured using semi-automatic BioPlus equipment (Bio-2000) and specific commercial kits. Serum globulin levels were calculated as the difference between serum levels of total proteins and albumin.

\subsection{Oxidizing and antioxidant status}

Serum activities of glutathione S-transferase (GST), superoxide dismutase (SOD), and catalase (CAT) were measured. GST activity was measured according to Mannervik and Guthenberg (1981), with modifications. Briefly, GST activity was measured as the rate of formation of dinitrophenyl-S-glutathione at $340 \mathrm{~nm}$ in a medium containing $50 \mathrm{mM}$ potassium phosphate at pH 6.5, 1 mM GSH, 1 mM 1-chloro-2, 4-dinitrobenzene (CDNB) as substrate and tissue supernatants (approximately $0.045 \mathrm{mg}$ protein). The results were expressed as U GST/mg protein. The activity of the SOD was measured using the method of Marklund and Marklund (1974), and the results were expressed as nmol SOD/mg of protein. CAT activity was measured using ultraviolet spectrometry, according to the method described by Aebi (1984), and the results were expressed as nmol CAT/mg of protein.

The levels of reactive oxygen species (ROS) in plasma were analyzed by the method described by Halliwell and Gutteridge (2007). The plasma $(10 \mu \mathrm{L})$ was incubated with $12 \mu \mathrm{L}$ of dichlorofluorescein (DFC) per $\mathrm{mL}$ at $37^{\circ} \mathrm{C}$ for $1 \mathrm{~h}$ in the dark. Fluorescence was determined using $488 \mathrm{~nm}$ for excitation and $520 \mathrm{~nm}$ for emission. The results were expressed as UDCF/mg protein. NOx levels were measured according to Miranda et al. (2001), which indirectly quantifies nitrite/nitrate levels, and the results were expressed as U NOx/mg protein. TBARS values were obtained using the method described by Ohkawa et al. (1978) in tissues and Jentzsch et al. (1996) in the plasma.

\subsection{Organ weight and histopathology}


Spleen and liver were weighed during the slaughter process. Then, fragments of the liver, intestine, and spleen were preserved in a formaldehyde solution (10\%). Tissue fragments were processed and placed in paraffin blocks. Then sections were made and stained with hematoxylin-eosin (HE).

\subsection{Statistical analysis}

The experimental design of this study was one factorial $2 \times 2$ [feed with and without aflatoxin (Afla and NoAfla) and with or without anti-mycotoxin (Anti-Myc and NoAnti-Myc)]. All data were analyzed using the MIXED procedure of SAS (SAS Inst. Inc., Cary, NC, USA; version 9.4), with Satterthwaite approximation to determine the denominator degrees of freedom for the test of fixed effects. The data of feed intake, weight gain, feed:gain ratiowere tested for fixed effects of aflatoxin, silymarin, and the interaction, and as a random effect was included pen (aflatoxin $\times$ silymarin). The data of antioxidant response in liver, spleen, and intestines variables were tested for fixed effects of aflatoxin, silymarin,n, and the interaction. Ass random effects were included pen (aflatoxin $\times$ anti-mycotoxin) and pigs (pen). All other data were analyzed as repeated measures (body weight and blood variables) and were included as fixed effects aflatoxin, antimycotoxin, day and all possible interactions, and as random effects were included pen (aflatoxin $\times$ anti-mycotoxin) and pig (pen). The covariance structures were selected according to the lowest Akaike information criterion. Means were separated using PDIFF, and all results were reported as LSMEANS followed by SEM. Significance was defined when P $\leq$ 0.05 and tendency when $\mathrm{P}>0.05$ and $\leq 0.10$.

\section{Results}

\subsection{Performance}

The body weight and weight gain of pigs that consumed feed contaminated with aflatoxin were lower than the other treatments (Table 2). DWG had an aflatoxin effect (days 1 to 10; 1 to 20, 1 to 30) and had an interaction between aflatoxin versus anti-mycotoxin (days 1 to 10; 1 to 30 and 21 to 30), i.e., piglets of the Afla-NoAntiMyc groups had lower DWG. Daily feed intake was lower in the Afla-No Anti Myc group in periods 1 to 20 and 1 to 30, which characterizes an aflatoxin effect (Table 2). There was no effect of the treatment and additive on feed conversion ratio.

\subsection{Serum biochemistry}

There was day versus AntiMyc interaction for total protein and globulin levels on days 20 and 40 of the experiment. Both variables had a higher concentration in the piglet serum that consumed the tested anti-mycotoxin blend (Table 3). Albumin levels were affected by the consumption of feed contaminated with aflatoxin, i.e., albumin levels in the serum of these piglets were higher (Table 3). Triglycerides and cholesterol did not differ between treatments, with no effect of aflatoxin and anti-mycotoxin blend.

ALT and AST activity affected aflatoxin and the anti-mycotoxin blend; there was an interaction of these variables with day (Table 3). We emphasize that aflatoxin consumption increased the aforementioned liver enzymes' activity, but when the anti-mycotoxin blend was added to the piglet's diet, the adverse effects on AST and ALT were avoided (Table 3; Figure 1).

\subsection{Hemogram}

There was no effect of aflatoxin consumption and anti-mycotoxin blend on erythrogram (total erythrocytes, hemoglobin, and hematocrit) (Table 4). There was also no effect of aflatoxin intake and anti-mycotoxin blend on total leukocytes, 
lymphocytes, and eosinophils during the experiment period; different from what happened with the number of neutrophils and monocytes (Table 4).

The consumption of aflatoxin by piglets caused a lower neutrophil count during the experimental period. There was a tendency toward a lower neutrophil count when the pigs consumed the anti-mycotoxin blend (Table 4). The consumption of the anti-mycotoxin blend influenced the monocyte count, which was lower (Table 4); in addition, there was an interaction between aflatoxin and anti-mycotoxin characterized by a higher monocyte count in piglets that ingested aflatoxin (Figure 2).

\subsection{Plasma, blood, and tissue antioxidant responses}

In the serum, antioxidant enzymes (GST, SOD, and CAT) and oxidizing biomarkers (NOx, ROS, and TBARS) did not differ between treatments, without the effect of aflatoxin and the consumption of the anti-mycotoxin blend (Table 5).

In the liver, there was an interaction between aflatoxin versus anti-mycotoxin for GST activity and ROS levels (Table 6); both variables had higher values (Afla-NoAntiMyc) when compared to other treatments. There was an interaction between aflatoxin versus anti-mycotoxin for ROS levels; that is, the piglets that consumed aflatoxin had higher ROS levels than other treatments (Table 6).

In the intestine, we verified the effect of the consumption of aflatoxin and the consumption of anti-mycotoxin for NOx levels; that is, piglets that consumed aflatoxin had higher NOx levels when compared to other treatments (Table 6). Aflatoxin led to a reduction in intestinal NOx levels, differently from the consumption of anti-mycotoxin blend, which increased NOx levels in the intestine (Table 6).

\subsection{Histopathology}

No intestinal, hepatic, and spleen lesions were observed in any treatment. There was an interaction between aflatoxin and anti-mycotoxin blend for fold size, villus height, and crypt depth (Table 7). Aflatoxin consumption decreased the fold-size but increased villus height and crypt depth. The consumption of the anti-mycotoxin blend minimized these changes regarding the fold and villus (Table 7).

\section{Discussion}

The consumption of diets with aflatoxin by pigs impaired weight gain, which was expected and made it possible to validate this study. According to Dilkin (2002), the ingestion of moderate or low doses of mycotoxins causes chronic mycotoxicosis interferes with productive performance, reducing the rate of feed conversion, weight gain, and reproductive efficiency. In swine herds that consumed different concentrations of aflatoxin, changes have already been described, such as lower feed consumption and gain and weight, in addition to higher mortality in higher concentrations (Cook, 1989). Wang (2020), in a recent survey of piglets, weaned and fed with diets contaminated with different levels of aflatoxin $(0,250$, and $500 \mathrm{ppb})$, observed that as the dose of mycotoxin increased, the rate of performance of these pigs decreased linearly, reaching a $25 \%$ reduction in GMD when administered with a diet containing $500 \mathrm{ppb}$ of aflatoxin, which is already known (Dilkin, 2002; Cook, 1985).

The anti-mycotoxin blend used in the present study minimized the adverse effects on weight gain caused by aflatoxin. The addition of adsorbents in animal feed to protect animals is a common practice (Huwig, 2001); however, blends have been a multifunctional alternative, that is, in addition to minimizing the effects of mycotoxins, it also has properties biological. Weaver (2013) evaluated the performance and health of pigs challenged by mycotoxins and fed 
simultaneously by three different types of adsorbents. It was found that the addition of adsorbents improved the health of the pigs and also favored the growth rate. This can be explained by the fact that aflatoxin, when absorbed by the gastrointestinal tract, can cause depression, diarrhea, and inappetence, reducing food conversion and consequently weight gain (Dilkin, 2004).

However, when an adsorbent blend is used in the feed of pigs that are eating contaminated food, the adsorbent acts directly on the pigs's body, fixing itself on the mycotoxin and eliminating it in the urine and feces, preventing its absorption (Bretas, 2018) and consequently not compromising and impairing the pig's performance. In this specific case, it is possible to highlight the contribution of silymarin present in the composition of the blend used, as it has an anti-hepatotoxic action, stabilizes the membrane, protects and prevents lipid peroxidation (Bindoli, 1997, Magliulo, 1979, Yao-Cheng, 1991, Lastra, 1992, Muriel, 1992).

Considerable increase in liver enzymes (AST and ALT) in the serum of piglets that consumed aflatoxin was observed, which did not occur in the pigs' serum when they consumed the anti-mycotoxin blend; therefore, how directly or indirectly did it have a hepatoprotective effect, capable of preventing cellular damage to the liver. According to the literature, the consumption of aflatoxin by animals generates liver problems (De La Salud 1993; Shen, 1995; Lopez, 2002; Kamdem, 2006; Yarru, 2009). When the animal is intoxicated by ingesting products contaminated by aflatoxin, it is highly susceptible to several liver problems since it is the main target (Dilkin, 2004).

Among the most frequent problems that may occur are injuries defined by fatty degenerations, the proliferation of bile ducts, biochemical changes, and blood clotting (Borsa, 1998). According to Olinda (2016), when a significant increase in the enzymes ALT and AST is observed, it suggests possible liver problems (hepatocellular lesions) of acute, hyperacute, or chronic level, since these are synthesized at the mitochondrial level. It is essential to investigate and understand how the anti-mycotoxin blend was able to protect the liver, which may be related to the presence of $C$. marianum, an extract rich in silymarin, a component known for its hepatoprotective effect (Ferreira, 2011).

However, another blend similar to the one used here, containing S. cerevisiae lysate, was tested in laying hens challenged with FB1 and DON, with a protective effect on the liver (Dazuk, 2021, in press). Despite cellular damage caused by aflatoxin, the liver's functionality was not affected by interfering with production. However, the synthesis of albumin was increased in the serum of piglets that consumed aflatoxin. Other researchers have already described that as the concentration of the toxic substance (mycotoxins) in the food offered increased, albumin levels increased proportionally (Rotter, 1994).

Lower neutrophil counts were observed in the readers of the Afla500Anti0 group, a change not observed in the pigs of the Afla500Anti1000 group. As mycotoxin acts as an immunosuppressant (Sharma 1993), we believe that the blend was also able to avoid this hematological alteration resulting from the consumption of aflatoxin. However, the number of monocytes was lower in piglets in the Afla500Anti1000 group. Today it is known that humoral immunity is affected by several mycotoxins (Oswald, 1998; Bonde, 2000). In an evaluation of sows exposed to mycotoxins, macrophage and neutrophil activities were inhibited (Silvotti, 1997). An experiment with piglets in daycare exposed to food contaminated with aflatoxin demonstrated a lower activity of messenger RNA in pro-inflammatory and anti-inflammatory cytokines (Oswald, 2005), which also suggests our results.

GTS activity and ROS levels in the liver were elevated in the group of piglets exposed to mycotoxin (Afla500Anti0), similar to what happened in the spleen to concentrate ROS. In pig farming, oxidative stress is a significant problem in newly weaned piglets, as these piglets are in a more delicate period and are more susceptible to this problem (Amazan, 2012). According to Shi-Bin (2007), this stress in piglets compromises their entire development since it will reduce their digestibility of nutrients and consequently compromising their growth. When this imbalance occurs, the increase in ROS occurs, increasing the animal's susceptibility to triggering infectious diseases since this alteration compromises its 
immune system when at significantly exacerbated levels (Bergman, 2011). It is known that in pigs, one of the factors that corroborate for this oxidant-antioxidant imbalance to occur is the animals' diet, so it is essential to know the quality of the food available (Falowo, 2014); because ingredients and consequently food contaminated by mycotoxins cause oxidative stress for example (Hou, 2013), as well as compromising biological functions.

\section{Conclusion}

Aflatoxicosis in pigs' impaired growth and concludes that the tested anti-mycotoxin blend has a protective effect on the health of the pigs and, consequently, minimizes the aflatoxin effects in contaminated diets. The results suggest that the blend acts indirectly, differently from conventional adsorbents; that is, the blend, when consumed by animals, has biological properties capable of protecting the liver, the metabolic organ, mainly affected by intoxications aflatoxin.

\section{Declarations}

\section{Data availability}

All data and materials used in the experiment are available and are ready to be provided if needed.

\section{Funding}

None.

\section{Acknowledgments}

The authors thank the Brazilian National Council for Scientific and Technological Development - CNPq and the Scientific and Technological Research Support Foundation of Santa Catarina State - FAPESC.

Conflict of interest. The authors declare no conflicts of interest.

Ethics committee. At the State University of Santa Catarina, the ethics committee approved the project using animals in research, protocol number 8763030419 .

\section{Authors' contributions}

Tarasconi L, Paiano D, and Da Silva A.S. contributed to the design and implementation of the research to the analysis of the results. Morsch VM, Gloria EM, Mendes RE, Ternus EM, and Vedovatto M helped develop the project and its execution and financing. Cecere B, Dazuk V, Molosse, V, Deaolindo GL, and Strapazzon JV participated in the execution of the experiment and collection of samples and data. Bottari NB, Copetti PM, and Sareta L did the laboratory analysis and date. All authors discussed the results and contributed to the final manuscript.

\section{Consent to participate}

All names in the author list have been involved in various stages of experimentation or writing.

\section{Consent for publication}

All authors agree to submit the paper for publication in the Tropical Animal Health and Production.

\section{References}


1. Amazan, D., Rey, A.I., Fernández, E., López-Bote, C.J., 2012. Natural vitamin E (D-a-tocopherol) supplementation in drinking water prevents oxidative stress in weaned piglets. Livestock Science, 145, 55-62.

2. Bergman, I.M., 2011. Toll-like receptors (TLRs) and mannan-binding lectin (MBL): On constant alert in a hostile environment. Upsala Journal of Medical Sciences, 116, 90-99.

3. Bondy, G.S, Pestka, J.J., 2000. Immunomodulation by fungal toxin. Journal of Toxicology and Environmental Health Part B, 3, 109-143.

4. Borsa, A., Lopes, S.T.A., Santurio, J.M., Mallmann, C.A., Lopes, J.M., Fernandes, R.R., 1998. Enzimas de função hepática na aflatoxicose aguda experimental em frangos de corte. Ciência Rural, 28 (4), 587-590.

5. Bretas, A.A., 2018. Inclusión of mycotoxin adsorvents for piglets. Ces. Med. Vet. Zootec. [online], 13 (1), 80.

6. Büchl, N.R., Hutzler, M., Mietke-Hofmann, H., Wenning, M., Scherer, S., 2010. Differentiation of probiotic and environmental Saccharomyces cerevisiae strains in animal feed. Journal of applied microbiology, 109 (3), $783-791$.

7. Bünzen, S., Haese, D., 2006. Controle de micotoxinas na alimentação de aves e suínos. Revista Eletrônica Nutritime, $3(1), 305$.

8. Carrera-Quintanar, L., Funes, L., Viudes, E., Tur, J., Micol, V., Roche, E., Pons, A., 2012. Antioxidant effect of lemon verbena extracts in lymphocytes of university students performing aerobic training program. Scandinavian journal of medicine \& science in sports, 22(4), 454-461.

9. Conti, M., Malandrino, S., Magistretti, M.J., 1992. Protective activity of silipide on liver damage in rodents. The Japanese Journal of Pharmacology, 60 (4), 315-321.

10. Cook, W.O., Alstine, W.G.V., Osweiler, G.D., 1989. Aflatoxicosis in lowa swine: Eight cases (1983-1985). J.Am. Vet. Med. Ass.; Chicago, 194, 554-558.

11. De La Salud, O.M., 1983. Critérios de salud ambiental 11: Micotoxinas. Cidade de México: OSP.

12. De Vasconcellos Dias, T. F., De Lucena Arcanjo, L., Da Costa, G. L., Souza, C. S., De Lima, C.A.R., 2020. Controle de pragas e tratamento de grãos armazenados para uso em rações para animais. Research, Society and Development, 9(9), e739996964.

13. Di Gregorio, M.C., Neeff, D.V.D., Jager, A.V., Corassin, C.H., Carão, Á.C.D.P., Albuquerque, R.D., Azevedo A.C.D., Oliveira, C.A.F., 2014. Mineral adsorbents for prevention of mycotoxins in animal feeds. Toxin Reviews, 33 (3), 125-135.

14. Dilkin, P., Mallmann, C.A., 2004. Sinais clínicos e lesões causadas por micotoxinas. XI Encontro Nacional de Micotoxinas, 32-35.

15. Dilkin, P., 2002. Micotoxicose suína: aspectos preventivos, clínicos e patológicos. Biológico, 64(2), 187-191.

16. Falowo, A.B., Fayemi, P.O., Muchenje, V., 2014. Natural antioxidants against lipid-protein oxidative deterioration in meat and meat products: A review. Food Research International, 64, 171-181.

17. Ferreira, A.S.P., 2011. Hepatotoxicidade: há evidências para o uso de hepatoprotetores. Reunião com Expertos em Hepatotoxicidade da Sociedade Brasileira de Hepatologia: Analgésicos, Antitérmicos, Insumos Vegetais,

Fitoterápicos, Homeopáticos e AINEs, 30(1), 06-47.

18. Haková, H., Misurová, E., 1993. The effect of silymarin and gama radiation on nucleic acids in rats. Journal of Phamacy and Phamacology, 45(10), 910-912.

19. Haque, M.A, Wang, Y., Shen, Z., Li, X., Saleemi, M.K., He, C., 2020. Mycotoxin contamination and control strategy in human, domestic animal and poultry: A review, Microbial Pathogenesis.

20. Holanda, D.M., Yiannikouris, A., Kim, S.W., 2020. Investigation of the efficacy of a postbiotic yeast cell wall-based blend on newly-weaned pigs under a dietary challenge of multiple mycotoxins with emphasis on deoxynivalenol. Toxins, 12(8), 504. 
21. HOU, Y-J., Zhao, Y-Y., Xiong, B., Cui, X-S., Kim, N-H., Xu,Y-X., Sun, S-C., 2013. Mycotoxin-containing diet causes oxidative stress in the mouse. Plos one, 8(3), e60374.

22. Huwig, A., Freimund, S., Kappeli, O., Dutler, H., 2001. Mycotoxin detoxication of animal feed by different adsorbents. Toxicology Letters, 122, 179-188.

23. Kamdem, L. K., Meineke, I., Gödtel-Armbrust, U., Brockmöller, J., \& Wojnowski, L., 2006. Dominant contribution of P450 3A4 to the hepatic carcinogenic activation of aflatoxin B1. Chemical research in toxicology, 19(4), 577-586.

24. Lopez, C., Ramos, L., Bulacio, L., Ramadan, S., \& Rodriguez, F., 2002. Aflatoxin B1 content in patients with hepatic diseases. MEDICINA-BUENOS AIRES-, 62(4), 313-316.

25. Lorenz, D., Lücker, P. W., Mennicke, W. H., \& Wetzelsberger, N., 1984. Pharmacokinetic studies with silymarin in human serum and bile. Methods and Findings in Experimental and Clinical Pharmacology, 6(10), 655-661.

26. Magliulo, E., Scevola, D., Carosi, G.O., 1979. Investigations on the actions of silybin of regenerating rat liver. Arzneimittel Forschung, 29(7), 1024-1028.

27. Marconcin, S.A., Rose, P., Lenati, L., da Silva, A.V.F., 2009. Suplementação de lecitina de soja na ração de cães: estudo sobre o perfil hematológico. Revista Acadêmica Ciência Animal, 7(3), 289-297.

28. Muriel, P., Garciapiña, T., Perez-Alvarez, V., \& Mourelle, M., 1992. Silymarin protects against paracetamol-induced lipid peroxidation and liver damage. Journal of Applied Toxicology, 12(6), 439-442.

29. Murugesan, G.R., Ledoux, D.R., Naehrer, K., Berthiller, F., Applegate, T.J., Grenier, B., Phillips, T.D., Schatzmayr, G., 2015. Prevalence and effects of mycotoxins on poultry health and performance, and recent development in mycotoxin counteracting strategies. Poultry science, 94(6), 1298-1315.

30. Official Methods of Analysis, 2005. 18th Ed.; AOAC International, Gaithersburg.

31. Olinda, R.G., Lima, J.M., de Lucena, R.B., do Vale, A.M., Batista, J.S., de Barros, C.S.L., Riet-Correa, F., Medeiros Dantas, A.F., 2016. Aflatoxicose aguda em suínos no Nordeste do Brasil. Acta Scientiae Veterinariae, 44, 1-6.

32. Oswald, I.P., Marin, D.E., Bouhet, S., Pinton, P., Taranu, I., \& Accensi, F.J.F.A., 2005. Immunotoxicological risk of mycotoxins for domestic animals. Food additives and contaminants, 22 (4), 354-360.

33. Oswald, I.P., Comera, C., 1998. Immunotoxicity of mycotoxins. Revue de Médecine Vétérinaire, 149, 585-590.

34. Ramos, A.J., Hernandez, E., 1996. In vitro aflatoxin adsorption using a montmorillonite silicate. A study of adsorption isotherms. Anim. Feed Sci. Technol. 62, 263-269.

35. Rocha, M.D.D.; Maia, P.P., Rodrigues, M.A.C., Martins, I., 2008. Incidência de aflatoxinas em amostras de amendoim e paçoca comercializadas na cidade de Alfenas-MG, Brasil. Rev Bras Toxicol, 21(1), p. 16.

36. Rosély Schossler, D., Eduardo Schossler, J., Fontoura Silva, C., 1998. Avaliação clínica e enzimática de cães com hepatite tóxica aguda tratados pela silimarina. R. bras. Ci. Vet. 5(3), 104-109.

37. Rotter, B.A., Thompson, B.K., Lessard, M., Trenholm, H.L., \& Tryphonas, H., 1994. Influence of low-level exposure to Fusarium mycotoxins on selected immunological and hematological parameters in young swine. Toxicological Sciences, 23(1), 117-124.

38. Sharma, R.P., 1993. Immunotoxicity of mycotoxins. Journal of Dairy Science, Champaign, 76(3), 892-897.

39. Schoenau, L.S.F., Varaschin, M., Salles, M.W.S., Santurio, J.M., \& Barros, C.S.L.D., 1994. Aflatoxicosis in swine. Ciência Rural, 24(2), 349-354.

40. Shen, H. M., Ong, C. N., Lee, B. L., \& Shi, C. Y. (1995). Aflatoxin B1-induced 8-hydroxydeoxyguanosine formation in rat hepatic DNA. Carcinogenesis, 16(2), 419-422.

41. Shi-Bin, Y., Dai-Wen, C., Ke-Ying, Z., Bing, Y., 2007. Effects of Oxidative Stress on Growth Performance, Nutrient Digestibilities and Activities of Antioxidative Enzymes of Weanling Pigs. Asian-Australasian Journal of Animal Science, 20(10), 1600-1605. 
42. Silvotti, L.,Petterino, C., Bonomi, A., Cabassic, E., 1997. Immunotoxicological effects on piglets of feeding sows' diets containing aflatoxins. Veterinary Record, 141, 469-472.

43. Souto, P.D.C., Augusto, L., di Gregorio, M.C., \& de Oliveira, C.A.F., 2017. Major mycotoxicoses in swine. Veterinária e Zootecnia, 24(3), 480-494.

44. Valenzuela, A., Guerra, R., 1985. Protective effect of the flavonoid silybin dihemisuccinate on the toxicity of phenylhydrazine on rat liver. Febs Letters, 181(2), 291-294.

45. Wang, D., Lindemann, M.D., Estienne, M.J., 2020. Effect of Folic Acid Supplementation and Dietary Protein Level on Growth Performance, Serum Chemistry and Immune Response in Weanling Piglets Fed Differing Concentrations of Aflatoxin. Toxins, 12(10), 651.

46. Weaver, A. C., See, M. T., Hansen, J. A., Kim, Y. B., De Souza, A. L., Middleton, T. F., \& Kim, S. W. (2013). The use of feed additives to reduce the effects of aflatoxin and deoxynivalenol on pig growth, organ health and immune status during chronic exposure. Toxins, 5(7), 1261-1281.

47. Wu, C.G., Chamuleau, R.A.F.M., Bosch, K.S., \& Frederiks, W.M., 1993. Protective effect of silymarin on rat liver injury induced by ischemia. Virchows Archiv B, 64(1), 259-263.

48. Yao-Cheng, R., 1991. Advances in pharmacologica studies of silymarin. Memórias do instituto Oswaldo Cruz, Rio de Janeiro, 86(2), 78-85.

49. Yarru, L. P., Settivari, R. S., Antoniou, E., Ledoux, D. R., \& Rottinghaus, G. E. (2009). Toxicological and gene expression analysis of the impact of aflatoxin B1 on hepatic function of male broiler chicks. Poultry Science, 88(2), 360-371.

\section{Tables}

Table 1. Ingredients and nutritional composition of diets.

\begin{tabular}{llll} 
Ingredients, g/kg & Pre-initial I & Pre-initial II & Initial I \\
\hline Ground corn, 7.8\% CP & 400 & 500 & 650 \\
\hline Soybean flour, 46\% CP & 100 & 250 & 300 \\
\hline Pre-initial basemix1 & 500 & - & - \\
\hline Pre-initial basemix2 & - & 250 & - \\
\hline Initial basemix3 & - & - & 50 \\
\hline Calculated composition* & & & \\
\hline Crude protein, g/kg & 20.2 & 20.3 & 19.9 \\
\hline Metabolizable energy, Mcal/kg & 3.52 & 3.43 & 3.36 \\
\hline Calcium g/kg & 6.80 & 7.02 & 7.01 \\
\hline Available phosphorus, g/kg & 3.39 & 3.56 & 3.38 \\
\hline Digestible lysine, g/kg & 14.5 & 13.5 & 12.8 \\
\hline Digestible methionine, g/kg & 5.85 & 5.14 & 4.78 \\
\hline Digestible Threonine, g/kg & 1.16 & 1.08 & 1.02 \\
\hline
\end{tabular}

${ }^{1}$ Minimum guarantee levels/kg of product; Crude Protein (CP) 210 g; Ether extract 55 g; Calcium 10 g; Phosphorus 7 g; Sodium 6 g; Co 1.6 mg; Cu 300 mg; Fe 300 mg; I 3.6 mg; Mn 110 mg; If 0.8 mg; Zn 5.4 g; Cr 0.6 mg; Vit. At 29,000 IU; Vit. 
D3 6,000 IU; Vit. E 160 IU; Vit. K3 7 mg; Vit. B1 7 mg; Vit. B2 11 mg; Vit. B6 7 mg; Vit. B12 140 g; Folic acid 1.4 mg; Nicotinic acid 81 mg; Pantothenic acid 51 mg; Choline 1.9 g; Biotin 0.2 mg; Lysine 22 g; Methionine 8,000 mg; Phytase 1,000 FTU; Xylanase 3,000 EPU; S. cerevisiae $4.8 \times 10^{9}$; L. acidophilus $5.5 \times 10^{7} ;$ B. bifidum $3.9 \times 10^{7} ; B$. amyloliquefaciens $1.2 \times 10^{8}$. Maximum levels/kg of product: Humidity 90 g; Crude Fiber 20 g; Ca 14 g; ash $400 \mathrm{~g}$.

${ }^{2}$ Minimum guarantee levels/Kg of product: Crude Protein $160 \mathrm{~g}$; Ethereal Extract 50 g; Calcium 18 g; Phosphorus 10 g; Sodium 10 g; Co 3.2 mg; Cu 600 mg; Fe 600 mg; I 7.2 mg; Mn 220 mg; If 1.6 mg; Zn 10 g; Cr 1.2 mg; Vit. At 58,000 IU; Vit. D3 12,000 IU; Vit. And 320 IU; Vit. K3 14 mg; Vit. B1 14 mg; Vit. B2 23 mg; Vit. B6 14 mg; Vit. 280 mcg B12; Folic acid (min) 2.8 mg; Nicotinic acid (min) 163 mg; Pantothenic acid 102 mg; Choline 2,120 mg; Biotin 0.4 mg; Lysine 25 g; Methionine $10 \mathrm{~g}$; Phytase 2,000 FTU; Xylanase 6,000 EPU. Maximum levels/kg of the product: Humidity $50 \mathrm{~g}$; Crude Fiber $30 \mathrm{~g}$; Ca $25 \mathrm{~g}$; Ashes $450 \mathrm{~g}$.

${ }^{3}$ Minimum guarantee levels/Kg of product: Calcium 90 g; Phosphorus 20 g; Sodium 35 g; Cu 1000 mg; Fe 1000 mg; I 20 mg; Mn 500 mg; If 8 mg; Zn 15 g; Vit. At 180,000 IU; Vit. D3 36,000 IU; Vit. And 400 IU; Vit. K3 60 mg; Vit. B1 28 mg; Vit. B2 80 mg; Vit. B6 30 mg; Vit. 360 mcg B12; Folic acid 8 mg; Nicotinic acid 600 mg; Pantothenic acid 320 mg; Choline 3,120 mg; Biotin 2 mg; Lysine 40 g; Methionine 40 g; Threonine 5,500 mg; Zinc bacitracin 900 mg. Maximum levels/kg of product: Humidity $20 \mathrm{~g}$; Ashes $730 \mathrm{~g}$; Ca $160 \mathrm{~g}$.

* Values calculated based on the nutritional composition proposed by Rostagno et al. (2017) and the basemixqual's nutritional composition.

Table 2. Growth of piglets fed with diets containing aflatoxins and anti-mycotoxin blend. 
Combined treatments ${ }^{2}$

\begin{tabular}{|c|c|c|c|c|c|c|c|c|}
\hline Variables $^{1}$ & $\begin{array}{l}\text { NoAfla- } \\
\text { NoAntiMyc }\end{array}$ & $\begin{array}{l}\text { NoAfla- } \\
\text { AntiMyc }\end{array}$ & $\begin{array}{l}\text { Afla- } \\
\text { NoAntiMyc }\end{array}$ & $\begin{array}{l}\text { Afla- } \\
\text { AntiMyc }\end{array}$ & & $\begin{array}{l}\text { Afla } \times \\
\text { AntiMyc }\end{array}$ & Afla & AntiMyc \\
\hline Initial body weight, kg & 7.36 & 7.40 & 7.42 & 7.42 & 0.02 & 0.97 & 0.95 & 0.98 \\
\hline Final body weight, kg & $26.5^{a}$ & $25.9^{a}$ & $23.7^{b}$ & $25.5^{a}$ & 0.09 & 0.05 & 0.04 & 0.81 \\
\hline $\begin{array}{l}\text { Weight gain: } 1 \text { to } 40 \\
(\mathrm{~kg})\end{array}$ & $19.2^{a}$ & $18.5^{\mathrm{a}}$ & $16.2^{b}$ & $18.1^{a}$ & 0.06 & 0.04 & 0.03 & 0.74 \\
\hline
\end{tabular}

Daily feed intake

\begin{tabular}{lllllllll}
\hline d 1 to 10 & 0.29 & 0.29 & 0.24 & 0.28 & 0.02 & 0.42 & 0.15 & 0.47 \\
\hline d 1 to 20 & 0.46 & 0.45 & 0.41 & 0.41 & 0.03 & 0.70 & 0.05 & 0.78 \\
\hline d 1 to 30 & 0.66 & 0.58 & 0.53 & 0.51 & 0.04 & 0.60 & 0.05 & 0.60 \\
\hline d 21 to 30 & 0.99 & 0.80 & 0.76 & 0.80 & 0.06 & 0.12 & 0.11 & 0.29 \\
\hline d 31 to 40 & 1.18 & 1.08 & 1.05 & 1.10 & 0.06 & 0.20 & 0.36 & 0.64 \\
\hline
\end{tabular}

Daily weight gain

$(\mathrm{kg})$

\begin{tabular}{|c|c|c|c|c|c|c|c|c|}
\hline d 1 to 10 & $0.17^{a}$ & $0.18^{a}$ & $0.13^{b}$ & $0.17^{a}$ & 0.01 & 0.05 & 0.05 & 0.10 \\
\hline d 1 to 20 & 0.34 & 0.33 & 0.28 & 0.31 & 0.02 & 0.36 & 0.05 & 0.65 \\
\hline d 1 to 30 & $0.41^{a}$ & $0.37^{a}$ & $0.33^{b}$ & $0.38^{a}$ & 0.01 & 0.02 & 0.05 & 0.69 \\
\hline d 21 to 30 & $0.54^{\mathrm{a}}$ & $0.55^{\mathrm{a}}$ & $0.42^{b}$ & $0.51^{a}$ & 0.03 & $<0.01$ & 0.23 & 0.83 \\
\hline d 31 to 40 & 0.65 & 0.61 & 0.64 & 0.62 & 0.05 & 0.88 & 0.92 & 0.53 \\
\hline \multicolumn{9}{|c|}{ Feed:gain ratio } \\
\hline d 1 to 10 & 1.70 & 1.68 & 1.91 & 1.76 & 0.11 & 0.57 & 0.07 & 0.46 \\
\hline d 1 to 20 & 1.38 & 1.37 & 1.47 & 1.40 & 0.06 & 0.65 & 0.36 & 0.53 \\
\hline d 1 to 30 & 1.60 & 1.55 & 1.63 & 1.53 & 0.05 & 0.68 & 0.96 & 0.22 \\
\hline d 21 to 30 & 1.83 & 1.80 & 1.81 & 1.65 & 0.09 & 0.54 & 0.44 & 0.34 \\
\hline d 31 to 41 & 1.82 & 1.77 & 1.67 & 1.76 & 0.08 & 0.44 & 0.35 & 0.83 \\
\hline
\end{tabular}

${ }^{1}$ Initial body weight corresponds to day 1 of the experiment (piglets 26 days old); final body weight corresponds to day 40.

${ }^{2}$ In a factorial design $(2 \times 2)$ was include or not aflatoxin (NoAfla and Afla for 0 or $500 \mathrm{mg}$ of aflatoxin/ $\mathrm{kg}$ of concentrate, respectively) and also included or not anti-mycotoxin blend (NoAntiMyc and AntiMyc for 0 or $1000 \mathrm{mg}$ of anti-mycotoxin blend/kg of concentrate, respectively).

${ }^{3} \mathrm{Afla}$, aflatoxin; AntiMyc, anti-mycotoxin blend. ${ }^{\mathrm{a}-\mathrm{b}}$ Differs $(P \leq 0.05)$ between treatments (lines).

Table 3. Serum biochemistry of piglets fed with diets containing aflatoxins and anti-mycotoxin blend. 


\begin{tabular}{|c|c|c|c|c|c|c|c|c|c|c|}
\hline \multirow[t]{3}{*}{ Variables $^{1}$} & \multicolumn{2}{|c|}{ Aflatoxin ${ }^{2}$} & \multirow[t]{3}{*}{ SEM } & \multicolumn{2}{|c|}{$P$-values ${ }^{3}$} & \multicolumn{2}{|c|}{ Anti-mycotoxin blend ${ }^{2}$} & \multirow[t]{3}{*}{ SEM } & \multicolumn{2}{|l|}{$P_{\text {-values }}^{3}$} \\
\hline & NoAfla & Afla & & & Afla & NoAntiMyc & AntiMyc & & & AntiMyc \\
\hline & & & & x day & & & & & Day & \\
\hline $\begin{array}{l}\text { Total protein } \\
(\mathrm{mg} / \mathrm{dL})\end{array}$ & & & & 0.82 & 0.52 & & & & $<0.01$ & 0.41 \\
\hline d 1 & 5.07 & 5.08 & 0.21 & & & 5.25 & 4.90 & 0.29 & & \\
\hline d 10 & 5.07 & 5.08 & 0.21 & & & 5.25 & 4.90 & 0.29 & & \\
\hline d 20 & 6.62 & 6.52 & 0.21 & & & $6.17 b$ & $6.98 a$ & 0.20 & & \\
\hline d 30 & 5.87 & 5.47 & 0.21 & & & 5.57 & 5.77 & 0.20 & & \\
\hline d 40 & 6.32 & 6.23 & 0.21 & & & $5.82 b$ & $6.73 a$ & 0.20 & & \\
\hline Average & 5.68 & 5.79 & 0.11 & & & 5.61 & 5.85 & 0.13 & & \\
\hline $\begin{array}{l}\text { Albumin } \\
(\mathrm{mg} / \mathrm{dL})\end{array}$ & & & & 0.89 & 0.03 & & & & 0.51 & 0.47 \\
\hline d 1 & 2.78 & 3.15 & 0.22 & & & 2.78 & 3.15 & 0.22 & & \\
\hline d 10 & 2.78 & 3.14 & 0.22 & & & 2.78 & 3.14 & 0.22 & & \\
\hline d 20 & 2.66 & 2.95 & 0.15 & & & 2.86 & 2.75 & 0.15 & & \\
\hline d 30 & 3.33 & 3.39 & 0.15 & & & 3.41 & 3.32 & 0.15 & & \\
\hline d 40 & 2.69 & 2.96 & 0.15 & & & 2.87 & 2.77 & 0.15 & & \\
\hline Average & $2.85^{b}$ & $3.12^{\mathrm{a}}$ & 0.08 & & & 2.94 & 3.03 & 0.08 & & \\
\hline $\begin{array}{l}\text { Globulin } \\
(\mathrm{mg} / \mathrm{dL})\end{array}$ & & & & 0.48 & 0.90 & & & & $<0.01$ & 0.50 \\
\hline d 1 & 2.22 & 2.02 & 0.24 & & & 2.44 & 1.79 & 0.27 & & \\
\hline d 10 & 2.21 & 2.02 & 0.24 & & & 2.44 & 1.79 & 0.27 & & \\
\hline d 20 & 3.78 & 3.55 & 0.24 & & & $3.19 b$ & $4.14 a$ & 0.27 & & \\
\hline d 30 & 2.06 & 2.45 & 0.24 & & & 1.96 & 2.56 & 0.27 & & \\
\hline d 40 & 3.25 & 3.62 & 0.24 & & & $2.98 \mathrm{~b}$ & $3.89 a$ & 0.27 & & \\
\hline Average & 2.70 & 2.73 & 0.14 & & & & & & & \\
\hline $\begin{array}{l}\text { Cholesterol } \\
(\mathrm{mg} / \mathrm{dL})\end{array}$ & & & & 0.85 & 0.76 & & & & 0.68 & 0.23 \\
\hline d 1 & 68.8 & 78.3 & 6.07 & & & 65.8 & 81.2 & 6.10 & & \\
\hline d 10 & 67.1 & 62.3 & 6.07 & & & 64.8 & 64.5 & 6.10 & & \\
\hline d 20 & 53.2 & 56.9 & 6.07 & & & 55.1 & 55.2 & 6.10 & & \\
\hline d 30 & 55.2 & 53.8 & 6.07 & & & 51.3 & 57.7 & 6.10 & & \\
\hline d 40 & 72.1 & 70.6 & 6.07 & & & 70.3 & 72.3 & 6.10 & & \\
\hline Average & 63.3 & 64.4 & 2.37 & & & 61.8 & 66.2 & 2.44 & & \\
\hline
\end{tabular}


(mg/dL)

\begin{tabular}{|c|c|c|c|c|c|c|c|c|c|}
\hline d 1 & 43.9 & 56.0 & 11.7 & & & 50.5 & 48.7 & 11.7 & \\
\hline d 10 & 51.4 & 51.7 & 11.7 & & & 47.8 & 55.3 & 11.7 & \\
\hline d 20 & 24.33 & 30.3 & 11.7 & & & 26.9 & 27.7 & 11.7 & \\
\hline d 30 & 68.75 & 107.7 & 11.7 & & & 95.8 & 80.6 & 11.7 & \\
\hline d 40 & 31.9 & 31.8 & 11.7 & & & 34.3 & 29.4 & 11.7 & \\
\hline Average & 44.1 & 55.4 & 6.00 & & & 51.2 & 48.3 & 6.00 & \\
\hline ALT (U/L) & & & & 0.02 & $<0.01$ & & & 0.05 & $<0.01$ \\
\hline d 1 & 21.3 & 20.9 & 1.57 & & & 21.4 & 20.9 & 1.57 & \\
\hline d 10 & $25.5^{a}$ & $30.1^{b}$ & 1.57 & & & 29.1 & 26.6 & 1.57 & \\
\hline d 20 & $26.4^{b}$ & $34.8^{a}$ & 1.57 & & & $33.4 a$ & $27.8 b$ & 1.57 & \\
\hline d 30 & $29.4^{b}$ & $37.5^{\mathrm{a}}$ & 1.57 & & & $37.9 a$ & $28.8 b$ & 1.57 & \\
\hline d 40 & 34.2 & 34.1 & 1.57 & & & $36.4 a$ & $31.9 b$ & 1.57 & \\
\hline Average & $27.4^{b}$ & $31.5^{a}$ & 0.67 & & & $31.6 a$ & $27.3 b$ & 0.68 & \\
\hline AST (U/L) & & & & $<0.01$ & $<0.01$ & & & $<0.01$ & $<0.01$ \\
\hline d 1 & 42.9 & 43.4 & 2.48 & & & 44.6 & 41.6 & 2.48 & \\
\hline d 10 & 42.2 & 44.6 & 1.76 & & & 43.9 & 42.8 & 1.76 & \\
\hline $\mathrm{d} 20$ & $36.9 \mathrm{~b}$ & $47.0 \mathrm{a}$ & 1.76 & & & $49.8 a$ & $34.1 b$ & 1.76 & \\
\hline d 30 & $39.3 b$ & $57.6 a$ & 1.76 & & & $59.7 a$ & $37.3 b$ & 1.76 & \\
\hline d 40 & $40.5 b$ & $48.9 a$ & 1.76 & & & $49.7 a$ & $39.7 b$ & 1.76 & \\
\hline Average & $40.4 b$ & $48.3 a$ & 0.92 & & & $49.5 a$ & $39.1 b$ & 0.91 & \\
\hline
\end{tabular}

${ }^{1} \mathrm{ALT}$ : alanine aminotransferase; AST: Aspartate aminotransferase.

${ }^{2}$ In a factorial design $(2 \times 2)$ was include or not aflatoxin (NoAfla and Afla for 0 or $500 \mathrm{mg}$ of aflatoxin/ $\mathrm{kg}$ of concentrate, respectively) and also included or not anti-mycotoxin blend (NoAntiMyc and AntiMyc for 0 or $1000 \mathrm{mg}$ of anti-mycotoxin blend/kg of concentrate, respectively).

${ }^{3} \mathrm{Afla}$, aflatoxin; AntiMyc, anti-mycotoxin blend.

${ }^{\text {a-b }}$ Differs $(P \leq 0.05)$ between treatments (lines).

Table 4. Hemogram of piglets fed with diets containing aflatoxins and silymarin. 


\begin{tabular}{|c|c|c|c|c|c|c|c|c|c|c|}
\hline \multirow[t]{2}{*}{ Variables $^{1}$} & \multicolumn{2}{|c|}{ Aflatoxin ${ }^{1}$} & \multirow[t]{2}{*}{ SEM } & \multicolumn{2}{|c|}{$P$-values ${ }^{2}$} & \multicolumn{2}{|c|}{ Anti-mycotoxin blend ${ }^{1}$} & \multirow[t]{2}{*}{ SEM } & \multicolumn{2}{|l|}{$P_{\text {-values }}{ }^{2}$} \\
\hline & NoAfla & Afla & & $\begin{array}{l}\text { Afla } \\
\times \\
\text { day }\end{array}$ & Afla & NoAntiMyc & AntiMyc & & $\begin{array}{l}\text { AntiMyc } \\
x\end{array}$ & AntiMyc \\
\hline $\begin{array}{l}\text { Erythrocytes } \\
\left(x 10^{6} \mu \mathrm{L}\right)\end{array}$ & & & & 0.89 & 0.46 & & & & 0.32 & 0.61 \\
\hline d 1 & 6.16 & 6.76 & 0.68 & & & 6.63 & 6.29 & 0.68 & & \\
\hline d 10 & 10.6 & 11.3 & 0.48 & & & 10.2 & 11.7 & 0.48 & & \\
\hline d 20 & 6.07 & 5.85 & 0.48 & & & 6.13 & 5.79 & 0.48 & & \\
\hline d 30 & 5.40 & 5.57 & 0.48 & & & 5.46 & 5.51 & 0.48 & & \\
\hline d 40 & 6.36 & 6.39 & 0.48 & & & 6.42 & 6.33 & 0.48 & & \\
\hline Average & 6.93 & 7.18 & 0.23 & & & & & & & \\
\hline Hematocrit (\%) & & & & 0.32 & 0.12 & & & & 0.22 & 0.11 \\
\hline d 1 & 38.7 & 38.0 & 1.26 & & & 37.9 & 38.8 & 1.27 & & \\
\hline d 10 & 38.8 & 38.2 & 1.26 & & & 39.2 & 37.9 & 1.27 & & \\
\hline d 20 & 37.2 & 39.6 & 1.26 & & & 38.9 & 37.9 & 1.27 & & \\
\hline d 30 & 36.8 & 40.6 & 1.26 & & & 40.9 & 36.5 & 1.27 & & \\
\hline d 40 & 32.8 & 34.1 & 1.26 & & & 35.4 & 31.5 & 1.27 & & \\
\hline Average & 36.8 & 38.1 & 0.53 & & & 38.4 & 36.5 & 0.54 & & \\
\hline $\begin{array}{l}\text { Hemoglobin } \\
(\mathrm{g} / \mathrm{dL})\end{array}$ & & & & 0.99 & 0.13 & & & & 0.96 & 0.78 \\
\hline d 1 & 10.4 & 10.8 & 0.52 & & & 10.6 & 10.6 & 0.52 & & \\
\hline d 10 & 12.1 & 12.5 & 0.37 & & & 12.2 & 12.3 & 0.37 & & \\
\hline $\mathrm{d} 20$ & 8.64 & 9.14 & 0.37 & & & 8.68 & 9.10 & 0.37 & & \\
\hline d 30 & 7.91 & 8.50 & 0.37 & & & 8.16 & 8.25 & 0.37 & & \\
\hline d 40 & 13.8 & 14.1 & 0.37 & & & 14.0 & 13.9 & 0.37 & & \\
\hline Average & 10.5 & 11.0 & 0.21 & & & 10.7 & 10.8 & 0.21 & & \\
\hline $\begin{array}{l}\text { Leukocyte } \\
\left(x 10^{3} / \mu \mathrm{L}\right)\end{array}$ & & & & 0.61 & 0.69 & & & & 0.21 & 0.76 \\
\hline d 1 & 9.72 & 9.85 & 1.32 & & & 10.1 & 9.40 & 1.32 & & \\
\hline d 10 & 18.5 & 18.1 & 0.93 & & & 17.4 & 19.1 & 0.93 & & \\
\hline $\mathrm{d} 20$ & 14.2 & 12.1 & 0.93 & & & 12.7 & 13.6 & 0.93 & & \\
\hline d 30 & 10.3 & 10.9 & 0.93 & & & 10.7 & 10.5 & 0.93 & & \\
\hline d 40 & 18.9 & 19.3 & 0.93 & & & 20.4 & 17.8 & 0.93 & & \\
\hline Average & 14.3 & 14.0 & 0.46 & & & 14.3 & 14.1 & 0.46 & & \\
\hline
\end{tabular}


$\left(\mathrm{x} 10^{3} / \mu \mathrm{L}\right)$

\begin{tabular}{|c|c|c|c|c|c|c|c|c|c|c|}
\hline d 1 & 5.70 & 6.04 & 0.90 & & & 6.04 & 5.71 & 0.90 & & \\
\hline d 10 & 9.04 & 6.69 & 0.90 & & & 8.84 & 6.89 & 0.90 & & \\
\hline d 20 & 6.81 & 4.21 & 0.90 & & & 5.42 & 5.60 & 0.90 & & \\
\hline d 30 & 4.13 & 2.91 & 0.90 & & & 3.91 & 3.13 & 0.90 & & \\
\hline d 40 & 10.6 & 6.63 & 0.90 & & & 9.57 & 7.66 & 0.90 & & \\
\hline Average & $7.26^{\mathrm{a}}$ & $5.30^{b}$ & 0.37 & & & $6.76^{a}$ & $5.80^{b}$ & 0.37 & & \\
\hline $\begin{array}{l}\text { Lymphocytes } \\
\left(x 10^{3} / \mu \mathrm{L}\right)\end{array}$ & & & & 0.42 & 0.20 & & & & 0.43 & 0.92 \\
\hline d 1 & 3.29 & 3.23 & 3.23 & & & 3.29 & 3.23 & 1.16 & & \\
\hline d 10 & 8.87 & 7.81 & 7.81 & & & 7.67 & 9.00 & 0.67 & & \\
\hline $\mathrm{d} 20$ & 6.64 & 6.58 & 6.58 & & & 6.27 & 6.95 & 0.67 & & \\
\hline d 30 & 4.74 & 4.96 & 4.96 & & & 5.07 & 4.64 & 0.67 & & \\
\hline d 40 & 7.42 & 8.97 & 8.97 & & & 9.08 & 7.31 & 0.67 & & \\
\hline Average & 6.19 & 6.31 & 0.35 & & & 6.27 & 6.23 & 0.35 & & \\
\hline $\begin{array}{l}\text { Monocytes } \\
\left(x 10^{3} / \mu \mathrm{L}\right)\end{array}$ & & & & 0.73 & 0.89 & & & & 0.75 & $<0.01$ \\
\hline d 1 & 0.86 & 0.41 & 0.27 & & & 0.90 & 0.37 & 0.27 & & \\
\hline d 10 & 1.65 & 1.88 & 0.27 & & & 1.93 & 1.60 & 0.27 & & \\
\hline $\mathrm{d} 20$ & 1.25 & 1.04 & 0.27 & & & 1.27 & 1.02 & 0.27 & & \\
\hline d 30 & 0.86 & 1.13 & 0.27 & & & 1.21 & 0.77 & 0.27 & & \\
\hline d 40 & 1.20 & 1.25 & 0.27 & & & 1.61 & 0.84 & 0.27 & & \\
\hline Average & 1.16 & 1.15 & 0.08 & & & $1.39^{a}$ & $0.93^{b}$ & 0.08 & & \\
\hline $\begin{array}{l}\text { Eosinophils } \\
\left(\times 10^{3} / \mu \mathrm{L}\right)\end{array}$ & & & & 0.74 & 0.35 & & & & 0.81 & 0.66 \\
\hline d 1 & 0.00 & 0.01 & 0.07 & & & 0.03 & 0.01 & 0.07 & & \\
\hline d 10 & 0.08 & 0.13 & 0.04 & & & 0.11 & 0.10 & 0.04 & & \\
\hline $\mathrm{d} 20$ & 0.14 & 0.22 & 0.04 & & & 0.16 & 0.20 & 0.04 & & \\
\hline d 30 & 0.12 & 0.09 & 0.04 & & & 0.11 & 0.10 & 0.04 & & \\
\hline d 40 & 0.17 & 0.23 & 0.04 & & & 0.23 & 0.17 & 0.04 & & \\
\hline Average & 0.10 & 0.14 & 0.02 & & & 0.13 & 0.11 & 0.02 & & \\
\hline
\end{tabular}

${ }^{1}$ Erythrocytes; Hematocrit; Hemoglobin; Leukocyte; Neutrophils; Lymphocytes; Monocytes; Eosinophils. 
${ }^{2}$ In a factorial design $(2 \times 2)$ was include or not aflatoxin (NoAfla and Afla for 0 or $500 \mathrm{mg}$ of aflatoxin/ $\mathrm{kg}$ of concentrate, respectively) and also included or not anti-mycotoxin blend (NoAntiMyc and AntiMyc for 0 or $1000 \mathrm{mg}$ of anti-mycotoxin blend/kg of concentrate, respectively).

${ }^{3}$ Afla, aflatoxin; AntiMyc, anti-mycotoxin blend.

${ }^{\mathrm{a}-\mathrm{b}}$ Differs $(P \leq 0.05)$ between treatments (lines).

Table 5. Serum antioxidant response of piglets fed with diets containing aflatoxins and Anti-Mycotoxin blend. 


\begin{tabular}{|c|c|c|c|c|c|c|c|c|c|c|}
\hline \multirow[t]{3}{*}{ Variables $^{1}$} & \multicolumn{2}{|c|}{ Aflatoxin ${ }^{2}$} & \multirow[t]{3}{*}{ SEM } & \multicolumn{2}{|c|}{$P$-values ${ }^{3}$} & \multicolumn{2}{|c|}{ Anti-mycotoxin blend ${ }^{2}$} & \multirow[t]{3}{*}{ SEM } & \multicolumn{2}{|l|}{ P-values ${ }^{3}$} \\
\hline & NoAfla & Afla & & & Afla & NoAntiMyc & AntiMyc & & AntiMyc $\times$ & AntiMyc \\
\hline & & & & \multicolumn{4}{|l|}{ × Day } & & \multicolumn{2}{|l|}{ Day } \\
\hline GST & & & & 0.67 & 0.77 & & & & 0.95 & 0.91 \\
\hline d 1 & 81.8 & 78.3 & 21.5 & & & 83.3 & 76.8 & 21.6 & & \\
\hline d 10 & 82.3 & 84.2 & 15.9 & & & 86.9 & 79.7 & 16.5 & & \\
\hline d 20 & 112 & 105 & 15.9 & & & 104 & 114 & 15.9 & & \\
\hline d 30 & 114 & 113 & 15.9 & & & 107 & 119 & 15.9 & & \\
\hline d 40 & 219 & 251 & 15.9 & & & 235 & 235 & 15.9 & & \\
\hline Average & 122 & 126 & 10.4 & & & 123 & 125 & 10.4 & & \\
\hline SOD & & & & 0.82 & 0.93 & & & & 0.44 & 0.55 \\
\hline d 1 & 7.49 & 6.70 & 0.90 & & & 6.00 & 8.19 & 0.90 & & \\
\hline d 10 & 5.72 & 5.86 & 0.63 & & & 6.08 & 5.50 & 0.63 & & \\
\hline d 20 & 5.87 & 5.68 & 0.63 & & & 5.64 & 5.90 & 0.63 & & \\
\hline d 30 & 5.09 & 4.85 & 0.63 & & & 5.09 & 4.85 & 0.63 & & \\
\hline d 40 & 7.89 & 8.77 & 0.63 & & & 8.40 & 8.26 & 0.63 & & \\
\hline Average & 6.41 & 6.37 & 0.34 & & & 6.24 & 6.54 & 0.34 & & \\
\hline CAT & & & & 0.57 & 0.89 & & & & 0.47 & 0.92 \\
\hline d 1 & 15.3 & 11.7 & 1.95 & & & 15.5 & 11.5 & 1.95 & & \\
\hline d 10 & 15.6 & 17.3 & 1.95 & & & 15.4 & 17.5 & 1.95 & & \\
\hline $\mathrm{d} 20$ & 18.1 & 18.8 & 1.95 & & & 19.1 & 17.7 & 1.95 & & \\
\hline d 30 & 14.5 & 17.0 & 1.95 & & & 14.7 & 16.9 & 1.95 & & \\
\hline d 40 & 15.8 & 15.1 & 1.95 & & & 14.6 & 16.3 & 1.95 & & \\
\hline Average & 16.0 & 15.8 & 0.70 & & & 15.9 & 16.0 & 0.72 & & \\
\hline NOX & & & & 0.69 & 0.47 & & & & 0.49 & 0.95 \\
\hline d 1 & 0.30 & 0.29 & 0.35 & & & 0.31 & 0.28 & 0.35 & & \\
\hline d 10 & 0.36 & 0.28 & 0.25 & & & 0.42 & 0.22 & 0.25 & & \\
\hline $\mathrm{d} 20$ & 0.35 & 0.94 & 0.25 & & & 0.37 & 0.92 & 0.25 & & \\
\hline d 30 & 1.04 & 1.27 & 0.25 & & & 1.10 & 1.20 & 0.25 & & \\
\hline d 40 & 0.43 & 0.40 & 0.29 & & & 0.60 & 0.23 & 0.29 & & \\
\hline Average & 0.49 & 0.63 & 0.12 & & & 0.56 & 0.57 & 0.12 & & \\
\hline ROS & & & & 0.66 & 0.90 & & & & 0.38 & 0.63 \\
\hline d 1 & 314 & 273 & 28.1 & & & 270 & 317 & 28.1 & & \\
\hline
\end{tabular}




\begin{tabular}{|c|c|c|c|c|c|c|c|}
\hline d 10 & 329 & 356 & 19.9 & 324 & 360 & 19.9 & \\
\hline d 20 & 271 & 282 & 19.9 & 283 & 270 & 19.9 & \\
\hline d 30 & 249 & 239 & 19.9 & 250 & 238 & 19.9 & \\
\hline d 40 & 257 & 277 & 19.9 & 280 & 255 & 19.9 & \\
\hline Average & 284 & 286 & 9.53 & 281 & 288 & 9.53 & \\
\hline TBARS & & & 0.76 & 0.32 & & 0.21 & 0.45 \\
\hline d 1 & 24.2 & 21.7 & 2.85 & 16.0 & 19.9 & 2.85 & \\
\hline d 10 & 13.0 & 11.3 & 2.14 & 14.9 & 9.45 & 2.14 & \\
\hline d 20 & 11.2 & 11.5 & 2.04 & 11.7 & 11.0 & 2.04 & \\
\hline d 30 & 15.5 & 10.9 & 2.04 & 10.5 & 15.9 & 2.04 & \\
\hline d 40 & 10.3 & 10.5 & 2.04 & 10.8 & 9.96 & 2.04 & \\
\hline Average & 14.8 & 13.2 & 1.12 & 12.8 & 13.2 & 1.12 & \\
\hline
\end{tabular}

${ }^{1}$ GST: glutathione s-transferase; SOD: superóxido dismutase; CAT; catalase; NOx: nitric oxide; ROS: reactive oxygen species; TBARS: Thiobarbituric acid reactive substances

${ }^{2}$ In a factorial design $(2 \times 2)$ was include or not aflatoxin (NoAfla and Afla for 0 or $500 \mathrm{mg}$ of aflatoxin/ $\mathrm{kg}$ of concentrate, respectively) and also included or not anti-mycotoxin blend (NoAntiMyc and AntiMyc for 0 or $1000 \mathrm{mg}$ of anti-mycotoxin blend/kg of concentrate, respectively).

${ }^{3}$ Afla, aflatoxin; AntiMyc, anti-mycotoxin blend.

${ }^{\mathrm{a}-\mathrm{b}}$ Differs $(P \leq 0.05)$ between treatments (lines).

Table 6. Liver, spleen and intestine antioxidant concentration of piglets fed with diets containing aflatoxins and antimycotoxin blend. 
Combined treatments ${ }^{2}$

\begin{tabular}{|c|c|c|c|c|c|c|c|c|}
\hline \multirow[t]{2}{*}{ Variables $^{1}$} & \multirow{2}{*}{$\begin{array}{l}\text { NoAfla- } \\
\text { NoAntiMyc }\end{array}$} & \multirow{2}{*}{$\begin{array}{l}\text { NoAfla- } \\
\text { AntiMyc }\end{array}$} & \multirow{2}{*}{$\begin{array}{l}\text { Afla- } \\
\text { NoAntiMyc }\end{array}$} & \multirow{2}{*}{$\begin{array}{l}\text { Afla- } \\
\text { AntiMyc }\end{array}$} & & Afla $x$ & \multirow[t]{2}{*}{ Afla } & \multirow[t]{2}{*}{ AntiMyc } \\
\hline & & & & & & AntiMyc & & \\
\hline \multicolumn{9}{|l|}{ Liver } \\
\hline GST & $1319^{b}$ & $1519^{b}$ & $2275^{a}$ & $1621^{\mathrm{ab}}$ & 304 & 0.05 & 0.09 & 0.93 \\
\hline $\mathrm{NO}_{\mathrm{x}}$ & 0.46 & 0.47 & 0.63 & 0.51 & 0.08 & 0.47 & 0.22 & 0.53 \\
\hline ROS & $528^{b}$ & $534^{b}$ & $749^{a}$ & $534^{b}$ & 104 & 0.04 & 0.27 & 0.60 \\
\hline TBARS & 49.8 & 47.4 & 57.6 & 56.9 & 7.04 & 0.12 & 0.21 & 0.63 \\
\hline \multicolumn{9}{|l|}{ Spleen } \\
\hline GST & 666 & 745 & 715 & 605 & 170 & 0.59 & 0.79 & 0.93 \\
\hline $\mathrm{NO}_{\mathrm{X}}$ & 0.71 & 0.58 & 0.51 & 0.59 & 0.11 & 0.32 & 0.37 & 0.81 \\
\hline ROS & $566^{b}$ & $614^{b}$ & $989^{a}$ & $570^{b}$ & 151 & 0.04 & 0.12 & 0.13 \\
\hline TBARS & 42.5 & 44.9 & 37.3 & 39.3 & 4.26 & 0.96 & 0.22 & 0.61 \\
\hline \multicolumn{9}{|l|}{ Intestines } \\
\hline GST & 704 & 655 & 661 & 666 & 121 & 0.83 & 0.90 & 0.86 \\
\hline $\mathrm{NO}_{\mathrm{X}}$ & 0.47 & 0.61 & 0.32 & 0.45 & 0.06 & 0.95 & 0.05 & 0.05 \\
\hline ROS & 1048 & 922 & 847 & 863 & 126 & 0.59 & 0.33 & 0.67 \\
\hline TBARS & 18.3 & 15.4 & 12.4 & 15.3 & 2.28 & 0.22 & 0.20 & 0.98 \\
\hline
\end{tabular}

${ }^{1}$ GST: glutathione s-transferase; NOx: nitric oxide; ROS: reactive oxygen species; TBARS: Thiobarbituric acid reactive substances

${ }^{2}$ In a factorial design $(2 \times 2)$ was include or not aflatoxin (NoAfla and Afla for 0 or $500 \mathrm{mg}$ of aflatoxin/ $\mathrm{kg}$ of concentrate, respectively) and also included or not anti-mycotoxin blend (NoAntiMyc and AntiMyc for 0 or $1000 \mathrm{mg}$ of anti-mycotoxin blend/kg of concentrate, respectively).

${ }^{3}$ Afla, aflatoxin; AntiMyc, anti-mycotoxin blend.

${ }^{\text {a-b }}$ Differs $(P \leq 0.05)$ between treatments (lines).

Table 7. Intestinal morphometry of piglets exposed to aflatoxin and supplemented with anti-mycotoxin blend. 


\begin{tabular}{|c|c|c|c|c|c|c|c|c|}
\hline \multirow{3}{*}{ Variables $^{1}$} & \multicolumn{4}{|c|}{ Combined treatments ${ }^{2}$} & \multirow[t]{3}{*}{ SEM } & \multicolumn{3}{|l|}{$P$-values ${ }^{3}$} \\
\hline & NoAfla- & NoAfla- & Afla- & Afla- & & Afla $x$ & Afla & AntiMyc \\
\hline & NoAntiMyc & AntiMyc & NoAntiMyc & AntiMyc & & AntiMyc & & \\
\hline & $\mathrm{T} 1$ & T5 & T2 & T6 & & & & \\
\hline Fold $(\mu \mathrm{m})$ & $1643^{a}$ & $1450^{a}$ & $1282^{b}$ & $1397^{a b}$ & 67.7 & $<0.01$ & $<0.01$ & 0.36 \\
\hline Villi $(\mu \mathrm{m})$ & $296^{b}$ & $215^{c}$ & $326^{a}$ & $275^{b}$ & 14.9 & $<0.01$ & 0.05 & 0.02 \\
\hline Crypt $(\mu \mathrm{m})$ & $223^{b}$ & $207^{b}$ & $256^{a}$ & $250^{\mathrm{a}}$ & 11.4 & $<0.01$ & 0.61 & 0.84 \\
\hline
\end{tabular}

${ }^{1}$ In a factorial design $(2 \times 2)$ was include or not aflatoxin (NoAfla and Afla for 0 or $500 \mathrm{mg}$ of aflatoxin/ $\mathrm{kg}$ of concentrate, respectively) and also included or not anti-mycotoxin blend (NoAntiMyc and AntiMyc for 0 or $1000 \mathrm{mg}$ of anti-mycotoxin blend/kg of concentrate, respectively).

${ }^{2}$ Afla, aflatoxin; AntiMyc, anti-mycotoxin blend.

${ }^{\mathrm{a}-\mathrm{b}}$ Differs $(P \leq 0.05)$ between treatments (lines).

\section{Figures}
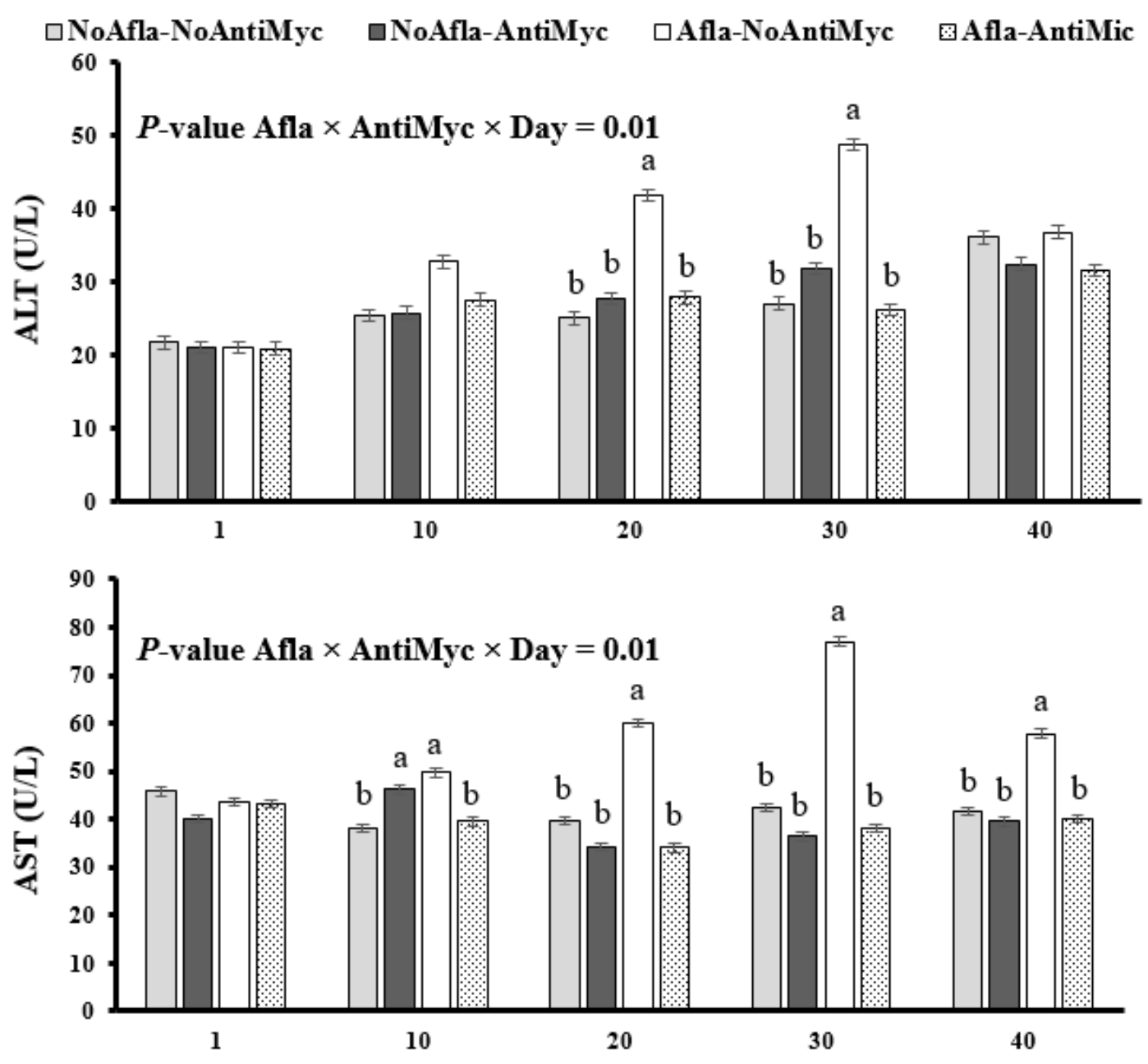
Figure 1

Serum concentration of alanine aminotransferase (ALT) and aspartate aminotransferase (AST of piglets fed with diets containing aflatoxins (Afla) and anti-mycotoxin blend (Anti-Myc). In a factorial design $(2 \times 2)$ was include or not aflatoxin (NoAfla and Afla for 0 or $500 \mathrm{mg}$ of aflatoxin/ $\mathrm{kg}$ of concentrate, respectively) and also included or not antimycotoxin blend (NoAntiMyc and AntiMyc for 0 or $1000 \mathrm{mg}$ of anti-mycotoxin blend/kg of concentrate, respectively). acDiffers $(P \leq 0.05)$ between treatments (lines). Vertical bars represent the SEM.

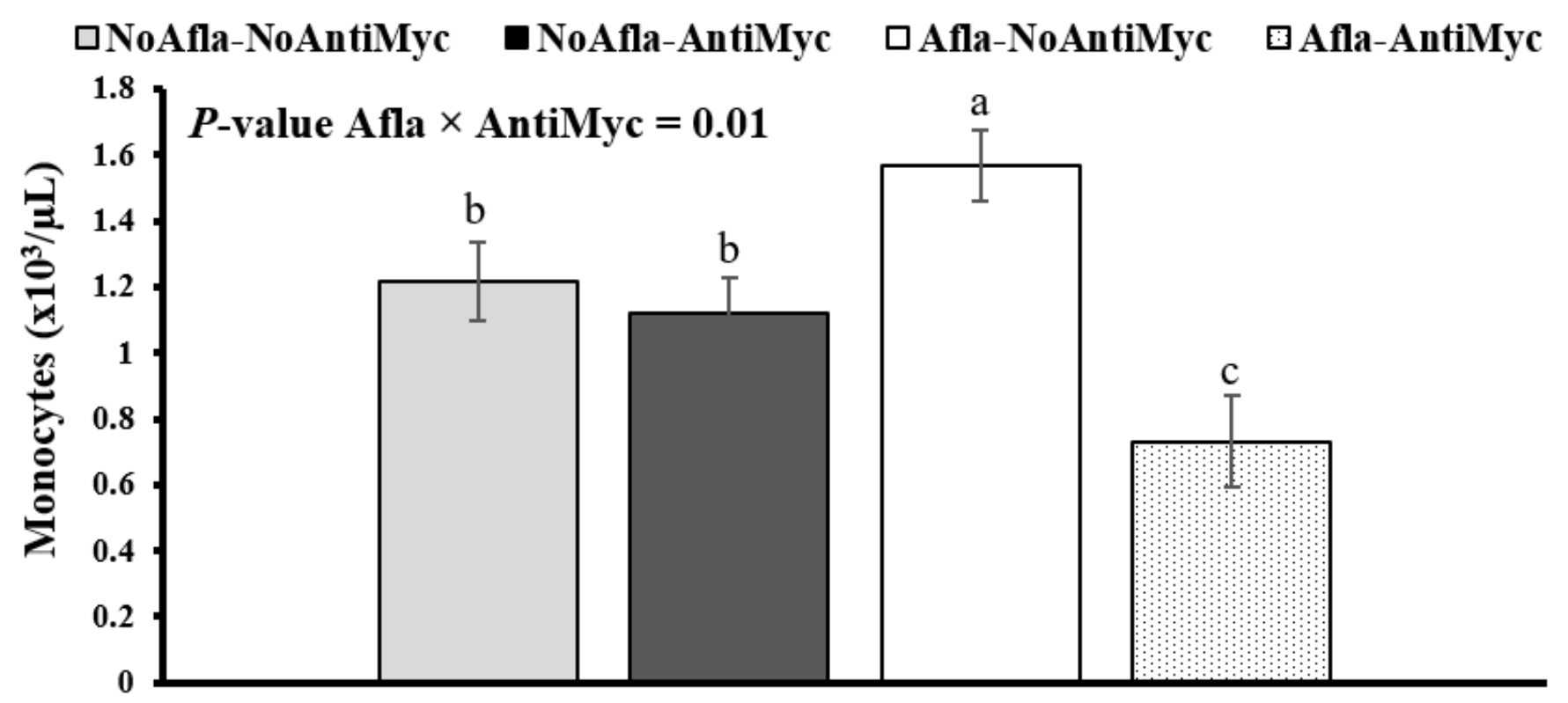

Figure 2

Number of monocytes of piglets fed with diets containing aflatoxins (Afla) and anti-mycotoxin blend (Anti-Myc). In a factorial design $(2 \times 2)$ was include or not aflatoxin (NoAfla and Afla for 0 or $500 \mathrm{mg}$ of aflatoxin/ $\mathrm{kg}$ of concentrate, respectively) and also included or not anti-mycotoxin blend (NoAntiMyc and AntiMyc for 0 or 1000 mg of anti-mycotoxin blend $/ \mathrm{kg}$ of concentrate, respectively). a-cDiffers $(P \leq 0.05)$ between treatments (lines). Vertical bars represent the SEM.

\section{Supplementary Files}

This is a list of supplementary files associated with this preprint. Click to download.

- SupplementaryMaterial1.docx 